\title{
Splenic Infection
}

National Cancer Institute

\section{Source}

National Cancer Institute. Splenic Infection. NCI Thesaurus. Code C78627.

An infectious process affecting the spleen. Predisposing factors include

immunosuppression, diabetes mellitus, and sickle cell anemia. Infectious agents include bacteria (e.g., staphylococcus and streptococcus) and fungi. 